\title{
Optimization of Maximum Power Point Tracking (MPPT) Using P\&O-Fuzzy and IC-Fuzzy Algorithms on Photovoltaic
}

\author{
Rido Octa Pratama ${ }^{*}$, Machmud Effendy ${ }^{2}$, Zulfatman ${ }^{3}$ \\ 1,2,3 Universitas Muhammadiyah Malang/Electrical Engineering \\ roctapratama@gmail.com¹ ${ }^{*}$ machmudefffendy@yahoo.com², zulfatman.@umm.ac.id ${ }^{3}$
}

\begin{abstract}
Solar energy is energy which can be harnessed conveniently and free. However, its conversion result may not be easily obtained. Based on the previous research, solar power plant is a source of renewable energy, utilizing solar energy. Solar power plant converts solar energy into electricity using Photovoltaic (PV) or solar cells. Even though solar power plant is considered as better energy alternative, it presents problems and weaknesses. In this case, the problems are related to insufficient power generation with low power efficiency, high oscillation and very slow power tracking. Hence, in order to solve these problems, Maximum Power Point Tracking (MPPT) has been utilized. Combination method of P\&O-fuzzy and IC-fuzzy is employed to its design. Moreover, combined algorithm may result better power from conventional algorithm due to appropriate performance of duty cycle according to system design, with efficiency result of 79\%$85.6 \%$, tracking in searching output power of $0,0055 \mathrm{~s}-0,008 \mathrm{~s}$, low oscillation and maximum power generated by combined algorithm of 1028 watt.
\end{abstract}

Keywords: Solar Cell, MPP, P\&O-Fuzzy, IC-Fuzzy

\section{Introduction}

Renewable energy has become a suitable solution to reduce the energy crisis and environmental issues in the world. Energy sources frequently used harness the existing natural resources such as water, sun, waves, wind and even geothermal. The utilization of renewable energy is also a reliable solution as a replacement of conventional energy sources which deplete their amount of reserves. One such renewable energy is photovoltaic [1].

While power generation using solar power is a great alternative to mitigate negative impacts on environmental issues, its application presents some problems. Those issues are exemplified by factors causing the electric power reduction generated by solar cells, such as solar intensity level and working temperature of the solar panels [2].

These problems may primarily persist if not utilizing Maximum Power Point Tracking (MPPT) control. MPPT is a control to maximize the performance of solar panels to obtain maximum power with good efficiency [3][4]. In the current MPPT, there are at least 19 different MPPT methods. Those methods are used as an algorithm to maximize the power attainment of solar cells. MPPT algorithms commonly used in the previous research are Perturb \& Observe (P\&O), Incremental Conductance (IC) and Fuzzy Logic Control (FLC) [5][6].

However, there are some existing weaknesses, such as not optimal power generation, frequently occurring oscillation around Maximum Power Point (MPP) area, slow tracking time to reach MPP value, unstable algorithm during climate changes, complexity in designing system algorithm and inaccuracy to achieve MPP value [7][8].

Therefore, we need a new technology to overcome the level of maximization of power output from solar cells; so that the power released can achieve maximum power with the resulting adequate efficiency. Afterwards, the method used in this study is a combination method between P\&O-fuzzy and IC-fuzzy, which is expected to achieve maximum power with a good level of accuracy. Low oscillation is obtained with quicker duration power generation and easier design development [9][10].

\section{Research Method}

\subsection{PV Design}

The value of PV parameters used in this simulation is KC200GT-200W type. Broadly speaking, the PV modeling is obtained from equations which have been adapted to the characteristics of PV itself in general. Figure 1 presents PV's schematic general circuit.

Pratama, R., Effendy, M., \& Zulfatman, Z. (2018). Optimization of Maximum Power Point Tracking (MPPT) Using P\&O-Fuzzy and IC-Fuzzy Algorithms on Photovoltaic. Kinetik, 3(2). doi:http://dx.doi.org/10.22219/kinetik.v3i2.200

Reveive April 28, 2017, Revise September 06, 2018, Accepted January, 022018 


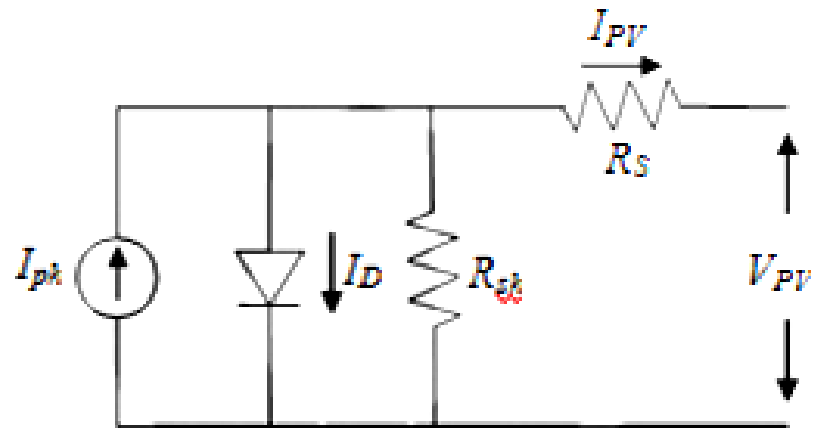

Figure 1. PV's Schematic General Circuit

PV parameters used in mathematical PV modeling are presented in Table 1.

Table 1. PV Parameters

\begin{tabular}{lcc}
\hline Characteristic & Unit & KC200GT-200W \\
\hline Maximum Power (Pmax) & W & 200.143 \\
Maximum Power Voltage (Vmp) & V & 26.3 \\
Maximum Power Current (Imp) & A & 7.61 \\
Short Circuit Current (Isc) & A & 8.21 \\
Open Circuit Voltage (Voc) & V & 32.9 \\
\hline
\end{tabular}

Equations 1 to 4 are mathematical formulas used to design solar cell in stages.

$$
\begin{gathered}
I_{p h}=\left(I_{s c}+K_{I}\left(T_{k}-T_{r e f}\right)\right) \frac{G}{G_{r e f}} \\
I_{r s}=\frac{I_{S c}}{\left[\exp \left(\frac{q V_{o c}}{N_{S} K A T}\right)-1\right]} \\
I_{s}=I_{r s}\left[\frac{T}{T_{r e f}}\right] \exp \left[\frac{q E_{g}}{A k}\left(\frac{1}{T_{r e f}}-\frac{1}{T}\right)\right] \\
I_{p v}=N_{p} I_{p h}-N_{p} I_{o}\left[\exp \left(\frac{q V_{o c}}{N_{S} K A T}\right)-1\right]
\end{gathered}
$$

Figure 2 shows mathematical PV designing which yields pure PV 200 Watts, increasing its power to 1200 Watts.

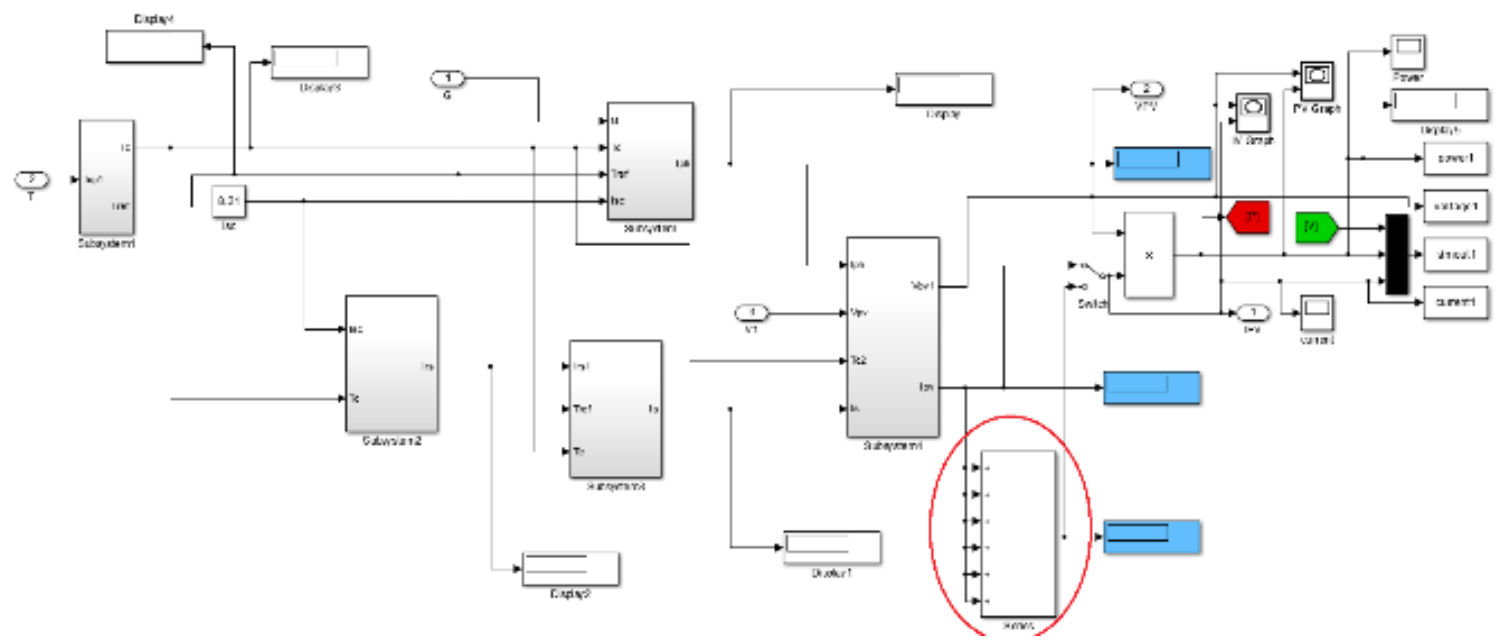

Figure 2. Mathematical PV Circuit

KINETIK Vol. 3, No. 2, May 2018: 119-134 
2.2 Maximum Power Point (MPPT) Design

MPPT is a method to find Maximum Power Point (MPP) or the maximum power point of power characteristic curve and input voltage (P-V) in solar panel application. Therefore, the existing system can work maximally and constantly. There are many algorithms used in MPPT; however, efficient, simple and accurate algorithms are required.

\subsubsection{MPPT Perturb and Observation (P\&O) Model}

Figure 3 and 4 present flowchart and P\&O circuit on Simulink MATLAB.

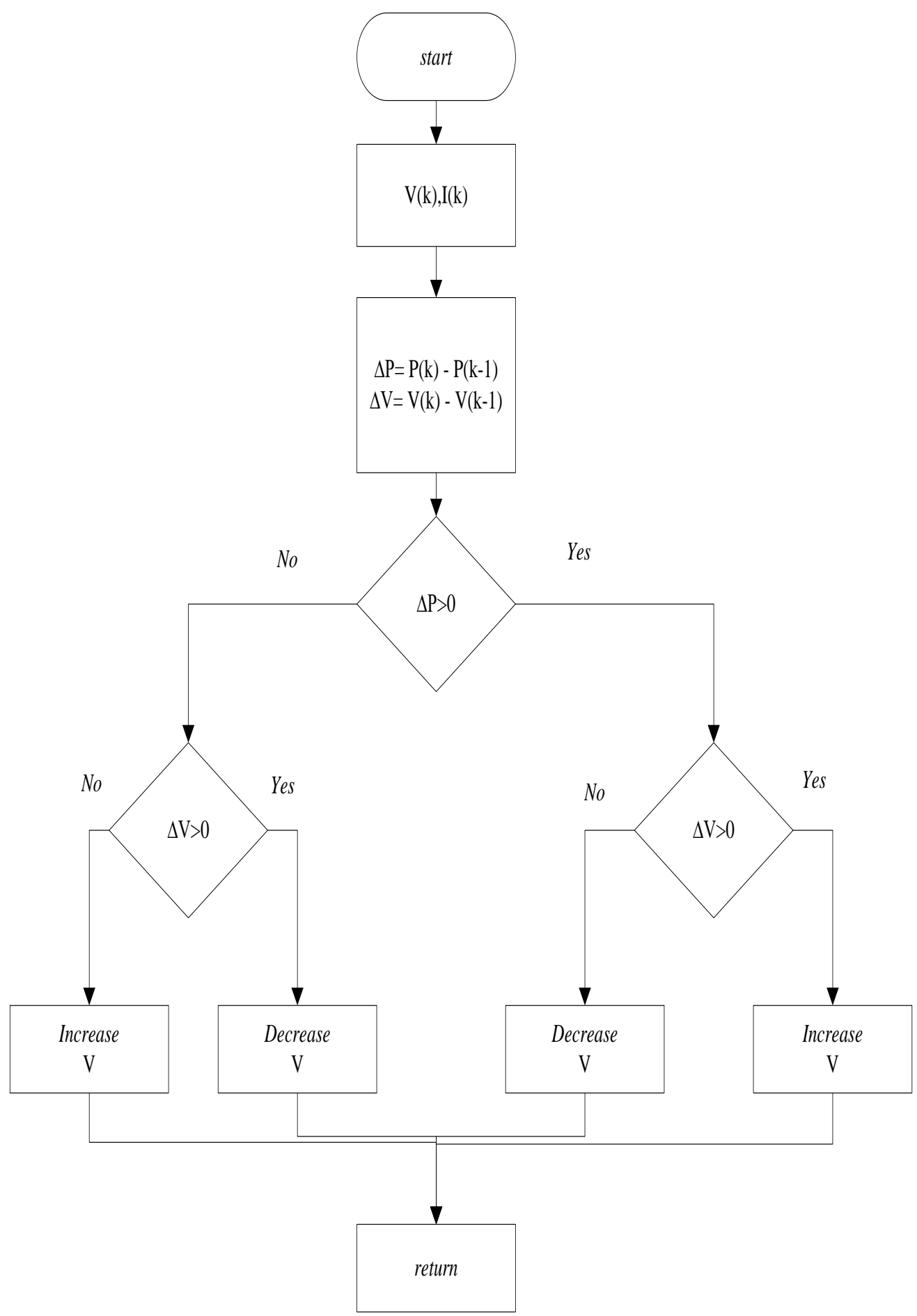

Figure 3. P\&O Algorithm Flowchart 


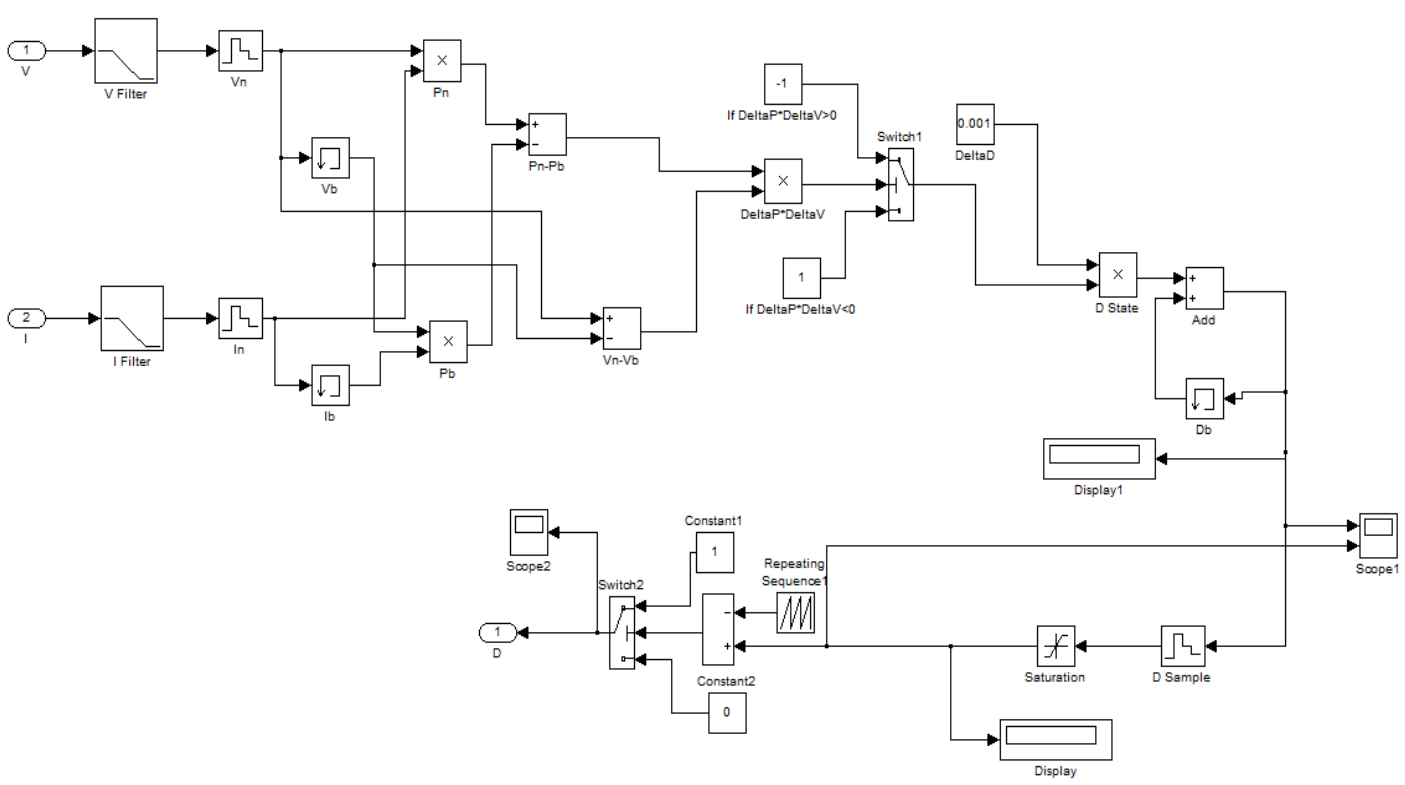

Figure 4. Simulink Block for P\&O Algorithm Modeling

2.2.2 MPPT Incremental Conductance (IC) Model

Figure 5 and 6 present flowchart and IC circuit on Simulink MATLAB.

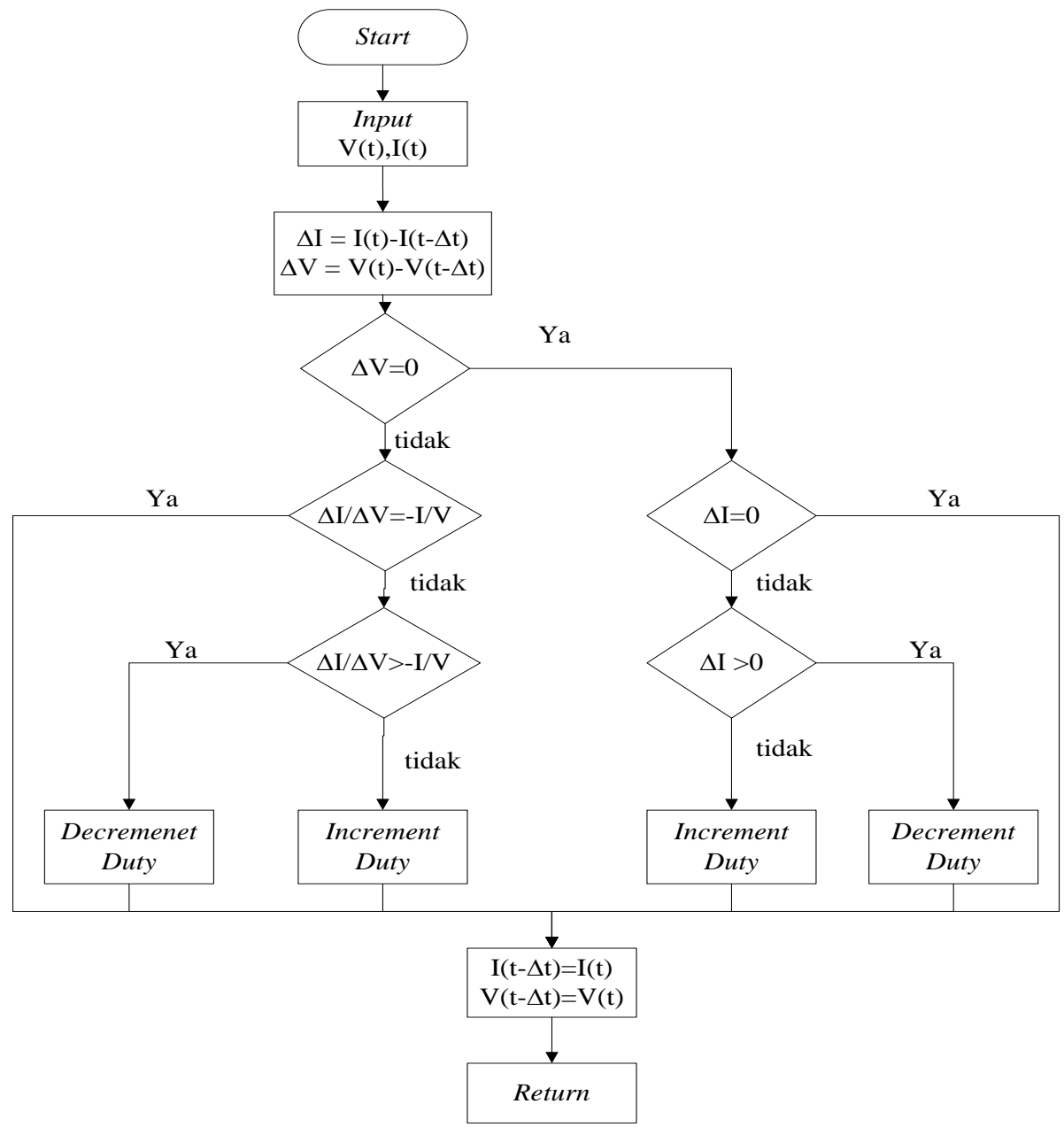

Figure 5. Incremental Conductance Flowchart

KINETIK Vol. 3, No. 2, May 2018: 119-134 


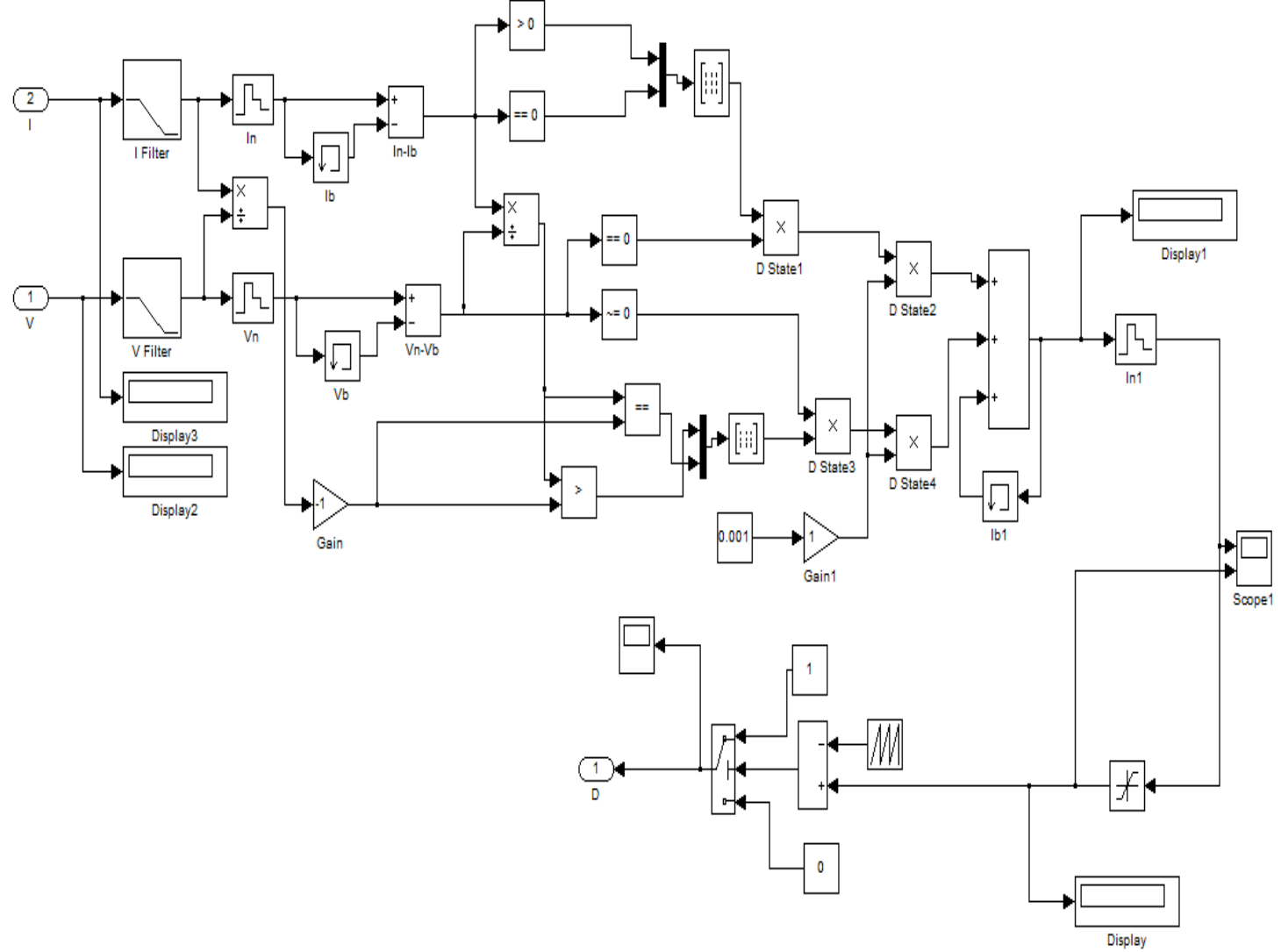

Figure 6. Simulink Block for IC Algorithm Modeling

\subsubsection{MPPT P\&O-Fuzzy Model}

On P\&O-fuzzy system designing, each of them uses 2 input variables.

a. $\Delta \mathrm{P}$ and $\Delta \mathrm{V}$

b. $S$ and $\Delta S$

c. $\mathrm{S}$ and $\Delta \mathrm{P}$

This stage utilizes five membership determinations on each variable, Big Negative (NB); Small Negative (NS); Zero (Z); Big Positive (PB); and Small Positive (PS). Each membership and fuzzy rule setting are as follows:

\subsubsection{Stages of Fuzzy Rule Determination for Variables $\Delta \mathbf{P}$ and $\Delta \mathbf{V}$}

Table 2 is a fuzzy rule design for $\Delta \mathrm{P}$ and $\Delta \mathrm{V}$ variables with designated regional analysis. Figure 7 fuzzy membership determination function for variables $\Delta \mathrm{P}$ and $\Delta \mathrm{V}$.

Table 2. Fuzzy Rule for Variables $\Delta P$ and $\Delta V$

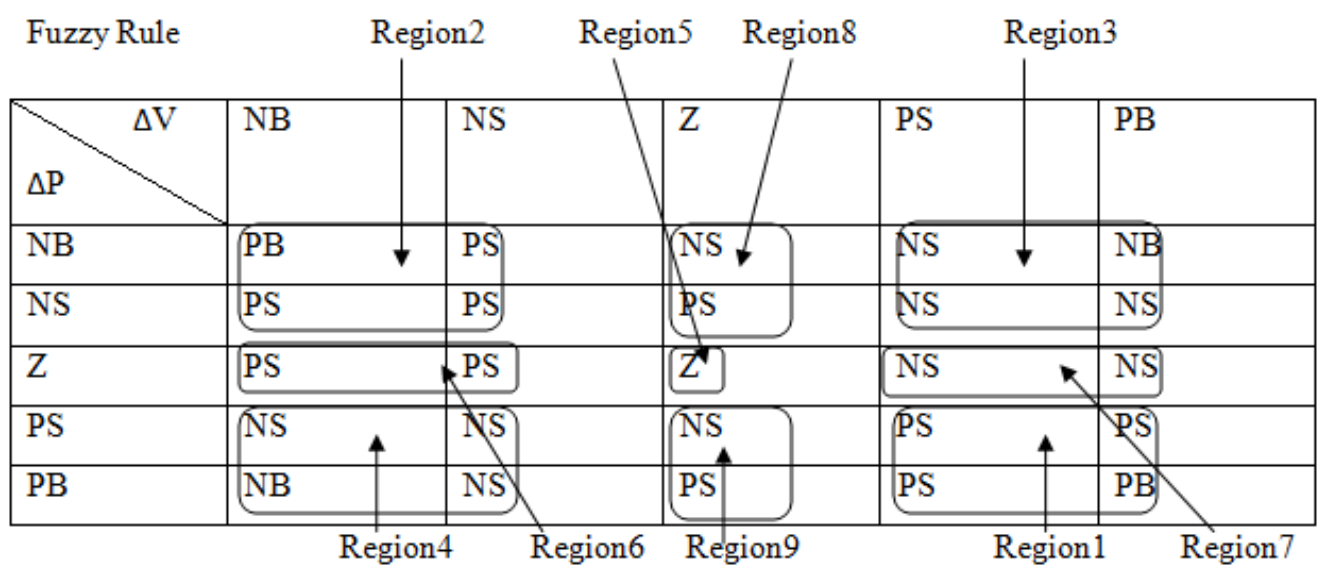




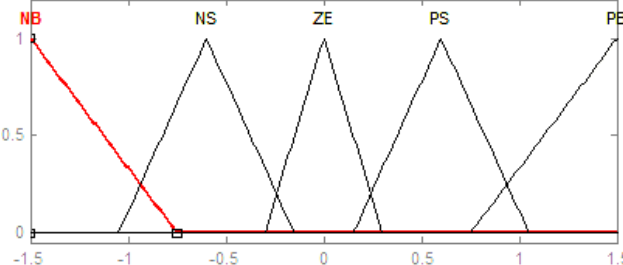

(a)

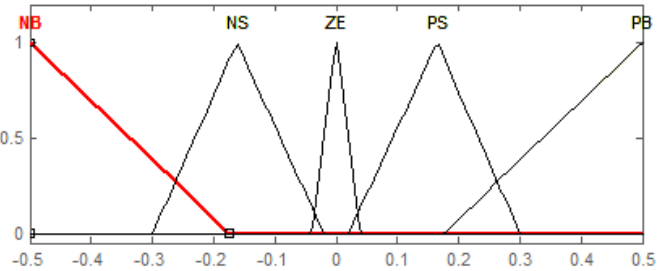

(b)

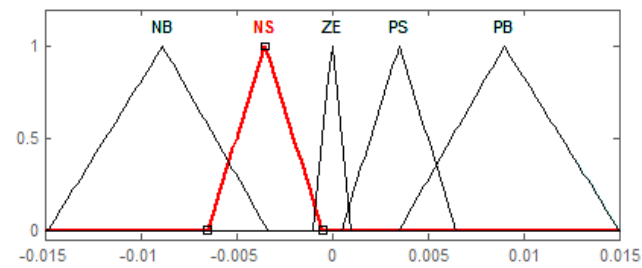

(c)

Figure 7. Membership Function for Variables $\Delta P$ and $\Delta V$ : (a) Membership Function for Input Variable $\Delta P$; (b) Membership Function for Input Variable $\Delta V$; and (c) Membership Function for the Alteration of Output Duty Cycle

\subsubsection{Final Stage of Fuzzy Rule for Variables $\mathbf{S}$ and $\Delta \mathrm{S}$}

Table 3 is a fuzzy rule design for variables $S$ and $\Delta S$ with the defined regional analysis designing. Figure 8 presents fuzzy membership determination function for variables $S$ and $\Delta S$.

Table 3. Fuzzy Rule for Variables $S$ and $\Delta S$

\begin{tabular}{|c|c|c|c|c|c|c|}
\hline \multirow{2}{*}{\multicolumn{2}{|c|}{ Fuzzy Rule }} & \multicolumn{5}{|c|}{$S(k)$} \\
\hline & & $\underline{\mathrm{NB}}$ & $\underline{\mathrm{NS}}$ & $\underline{\mathrm{ZE}}$ & $\underline{\mathbf{P S}}$ & $\underline{\mathrm{PB}}$ \\
\hline \multirow{5}{*}{$\Delta S(k)$} & $\underline{\mathrm{NB}}$ & $\mathrm{ZE}$ & PB & PS & $\mathrm{ZE}$ & NB \\
\hline & $\underline{\mathrm{NS}}$ & PB & PS & ZE & ZE & NB \\
\hline & $\underline{\mathrm{ZE}}$ & PB & PS & ZE & NS & NB \\
\hline & $\underline{\mathrm{PS}}$ & PB & ZE & ZE & NS & NB \\
\hline & $\underline{\mathrm{PB}}$ & PB & ZE & NS & NB & ZE \\
\hline
\end{tabular}

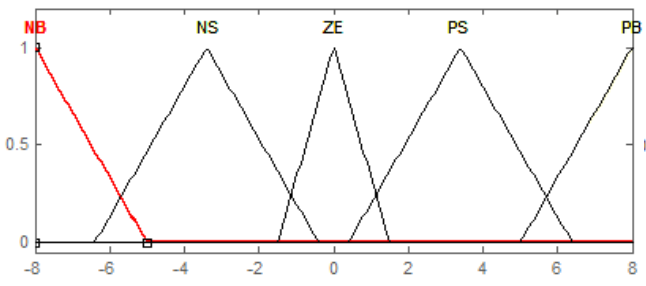

(a)

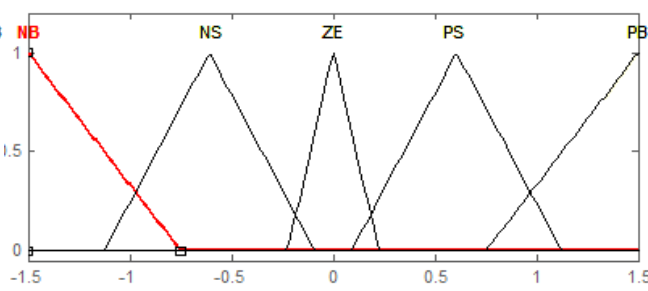

(b)

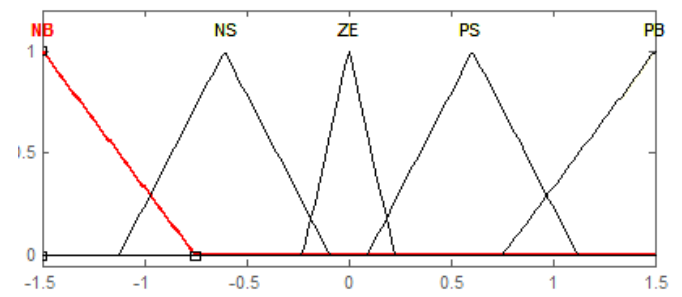

(c)

Figure 8. Membership Function for Variables $S$ and $\Delta S$ : (a) Membership Function for Input Variable S; (b) Membership Function for Input Variable $\Delta S$; and (c) Membership Function for the Alteration of Output Duty Cycle 


\subsubsection{Stage of Fuzzy Rule Determination for Variable $S$ and $\Delta P$}

Table 4 presents fuzzy rule designing for $S$ and $\Delta P$ using previously designated regional analysis designing. Figure 9 illustrates the determination of fuzzy membership function for variables $\mathrm{S}$ and $\Delta \mathrm{P}$.

Table 4. Fuzzy Rule for Variables $S$ and $\Delta P$

\begin{tabular}{|c|c|c|c|c|c|c|}
\hline \multirow{2}{*}{\multicolumn{2}{|c|}{ Fuzzy Rule }} & \multicolumn{5}{|c|}{$S(k)$} \\
\hline & & NB & $\underline{\text { NS }}$ & $\underline{\mathbf{Z E}}$ & PS & $\underline{\mathbf{P B}}$ \\
\hline \multirow{5}{*}{$\Delta P_{P V}$} & $\underline{\mathrm{NB}}$ & $\mathrm{PB}$ & $\mathrm{PB}$ & $\mathrm{ZE}$ & $\mathrm{NS}$ & $\mathrm{NB}$ \\
\hline & $\underline{\text { NS }}$ & PB & PS & ZE & NS & NB \\
\hline & $\underline{\mathbf{Z E}}$ & PS & PS & $\mathrm{ZE}$ & NS & NS) \\
\hline & $\underline{\text { PS }}$ & PB & PS & $\mathrm{ZE}$ & NS & NB \\
\hline & $\underline{\text { PB }}$ & PB & PS & 7F & NB & NB \\
\hline
\end{tabular}

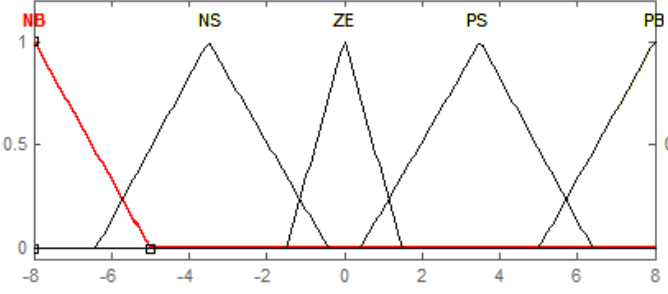

(a)

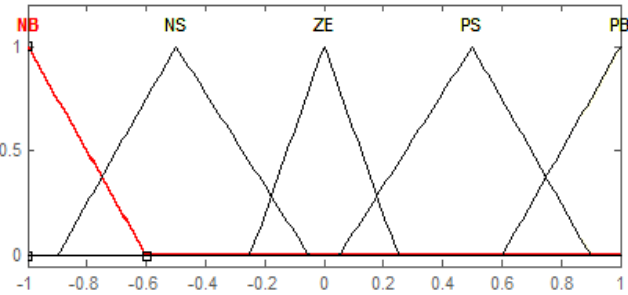

(b)

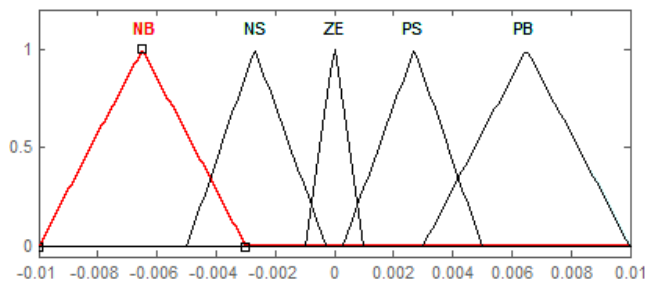

(c)

Figure 9. Membership Function for Variables $S$ and $\Delta P$ : (a) Membership Function for Input Variable $\Delta P$; (b) Membership Function for Input Variable S; and (c) Membership Function for Output Duty Cycle Alteration

\subsubsection{MPPT IC-Fuzzy Model}

Similarly, the design of the $\mathrm{P} \& \mathrm{O}$-fuzzy on IC-fuzzy system also uses two input variables $\Delta \mathrm{P}$ and $\Delta \mathrm{l}$ as well as by using one input and one output using tangent variable. Table 5 presents fuzzy rule design for variables $\Delta \mathrm{P}$ and $\Delta \mathrm{l}$ with designated regional analysis. Figure 10 shows the determination of the membership fuzzy function for variables $\Delta \mathrm{P}$ and $\Delta \mathrm{l}$.

\subsubsection{Stage of Fuzzy Rule on Tangent Variable}

Table 6 presents a fuzzy rule design using one input and one output for tangent variable with a predetermined regional analysis design. Figure 11 illustrates the determination of tangent variable for membership fuzzy function.

Figures 12 to 16 show P\&O-fuzzy and IC-fuzzy algorithm system designs using MATLAB Simulink. With variables already specified, Figure 17 presents an overall Simulink block using fuzzy system. 


\begin{tabular}{|c|c|c|c|c|c|c|}
\hline & & \multicolumn{2}{|c|}{ Region 1} & Region 2 & \multicolumn{2}{|c|}{ Region 3} \\
\hline \multirow{2}{*}{\multicolumn{2}{|c|}{ Fuzzy Rule }} & & & $\Delta P$ & & \\
\hline & & $\underline{\mathrm{NB}}$ & $\underline{\mathrm{NS}}$ & $\underline{Z E}$ & $\underline{\mathbf{P S}}$ & $\underline{\mathrm{PB}}$ \\
\hline \multirow{5}{*}{$\Delta I$} & $\underline{\mathrm{NB}}$ & $\mathrm{PB}$ & PS & $\mathrm{ZE}$ & NS & $\mathrm{NB}$ \\
\hline & $\underline{\mathrm{NS}}$ & PS & PS & $\mathrm{ZE}$, & NS & NS \\
\hline & $\underline{\mathrm{ZE}}$ & $\mathrm{ZE}$ & $\mathrm{ZE}$ & $\mathrm{ZE}$ & $\mathrm{ZE}$ & $\mathrm{ZE}$ \\
\hline & $\underline{\mathbf{P S}}$ & NS & NS & ZE & PS & PS \\
\hline & $\underline{\mathrm{PB}}$ & NB & NS & $\mathrm{ZE}$, & PS & PB \\
\hline & & \multicolumn{2}{|c|}{ Region 7} & Region 8 & \multicolumn{2}{|c|}{$\underset{\downarrow}{\downarrow}$} \\
\hline
\end{tabular}

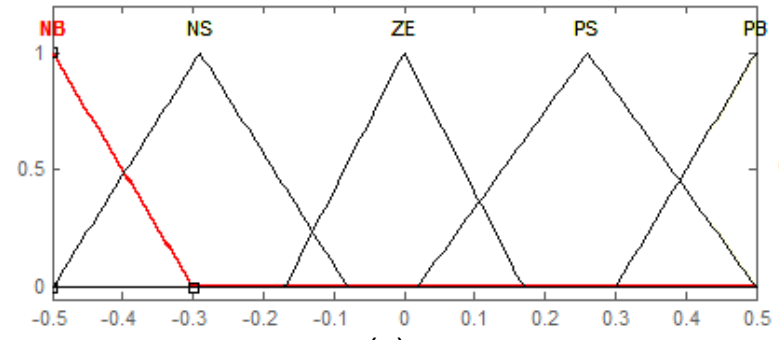

(a)

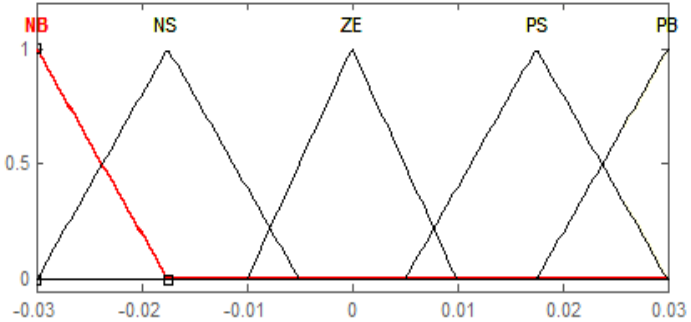

(b)

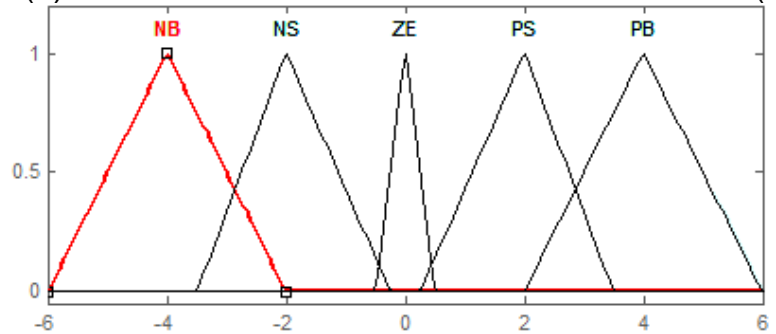

(c)

Figure 10. Membership Function for Variables $\Delta P$ and $\Delta l$ : (a) Membership Function for Input Variable $\Delta P$; (b) Membership Function for Input Variable $\Delta l$; and (c) Membership Function for Duty Output Cycle Alteration

Table 6. Fuzzy Rule for Tangent Variable

\begin{tabular}{|c|c|c|c|c|c|}
\hline \multirow{4}{*}{ Fuzzy Rule } & \multicolumn{5}{|c|}{$180^{\circ}-\left[\tan ^{-1}\left(\frac{I_{P V}}{V_{P V}}\right)+\tan ^{-1}\left(\frac{d I_{P V}}{d V_{P V}}\right)\right]$} \\
\cline { 2 - 6 } & $\mathbf{N B}$ & $\mathbf{N S}$ & $\mathbf{Z E}$ & $\mathbf{P S}$ & PB \\
\cline { 2 - 6 } & $\mathrm{NB}$ & $\mathrm{NS}$ & $\mathrm{ZE}$ & $\mathrm{PS}$ & $\mathrm{PB}$ \\
\hline
\end{tabular}

Region 1 Region 2 Region 3 


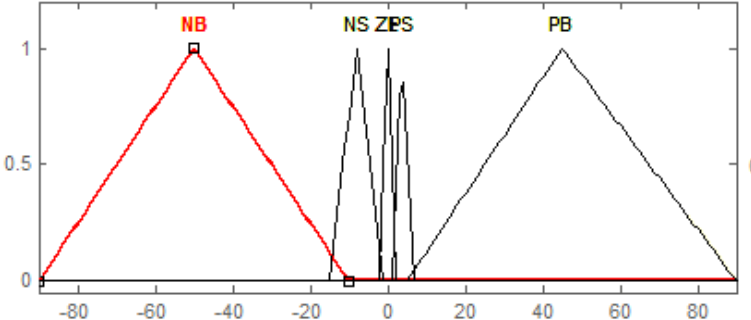

(a)

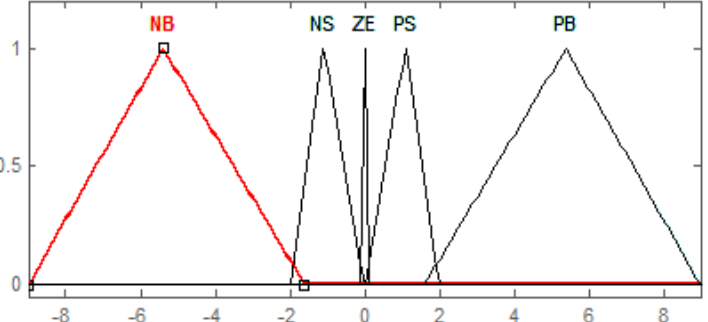

(b)

Figure 11. Membership Function for Tangent Variable: (a) Membership Function for Tangent Input Variable; and (b) Membership Function for Duty Output Cycle Alteration

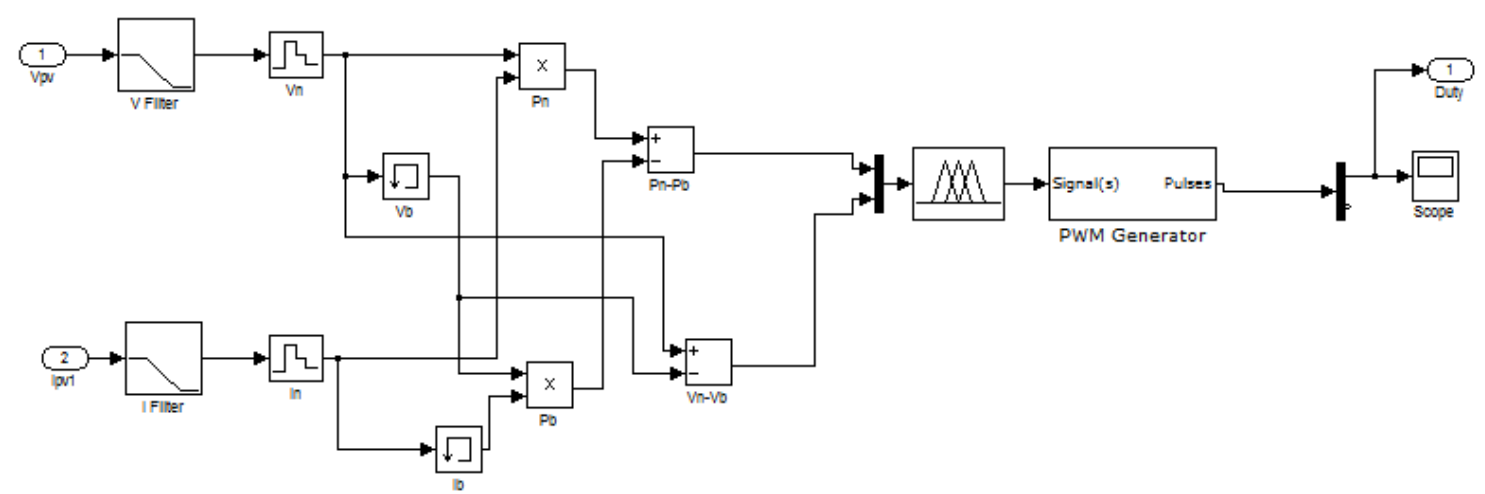

Figure 12. Simulink Block for P\&O-Fuzzy Algorithm Using Variables $\Delta P$ and $\Delta V$

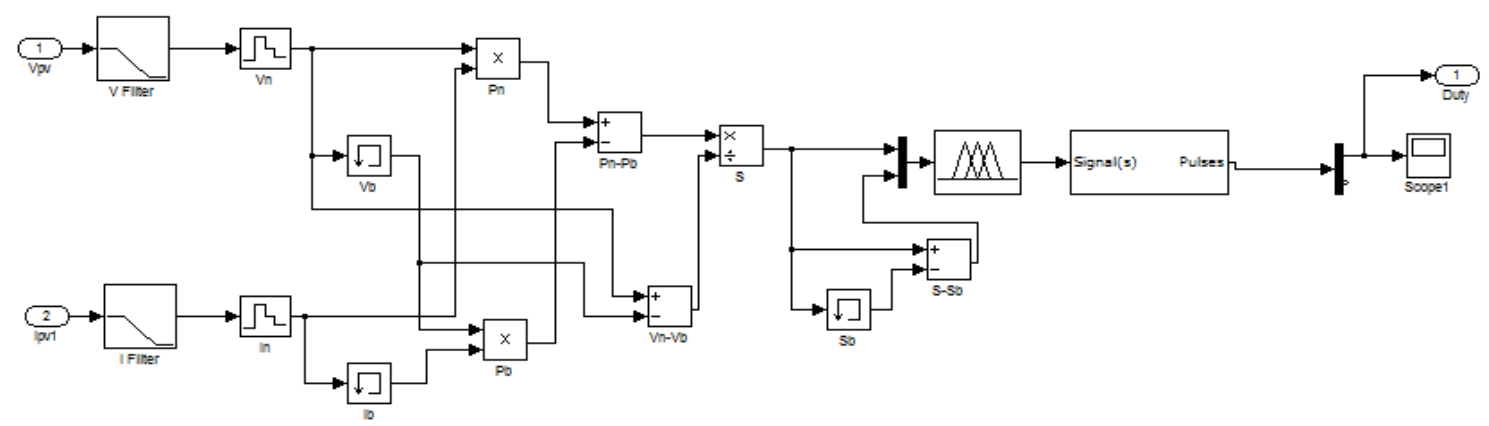

Figure 13. Simulink Block of P\&O-Fuzzy Algorithm Using Variables $S$ and $\Delta S$

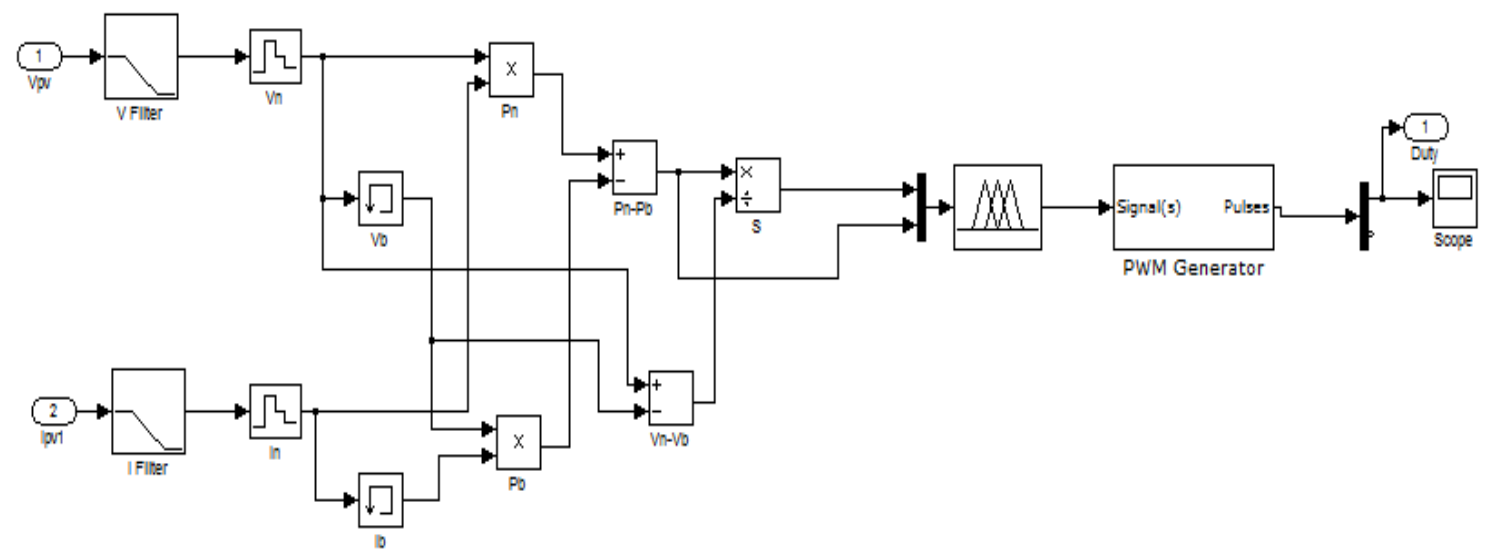

Figure 14. Simulink Bock of $P \& O$-fuzzy Algorithm Using Variables $S$ and $\Delta P$ 


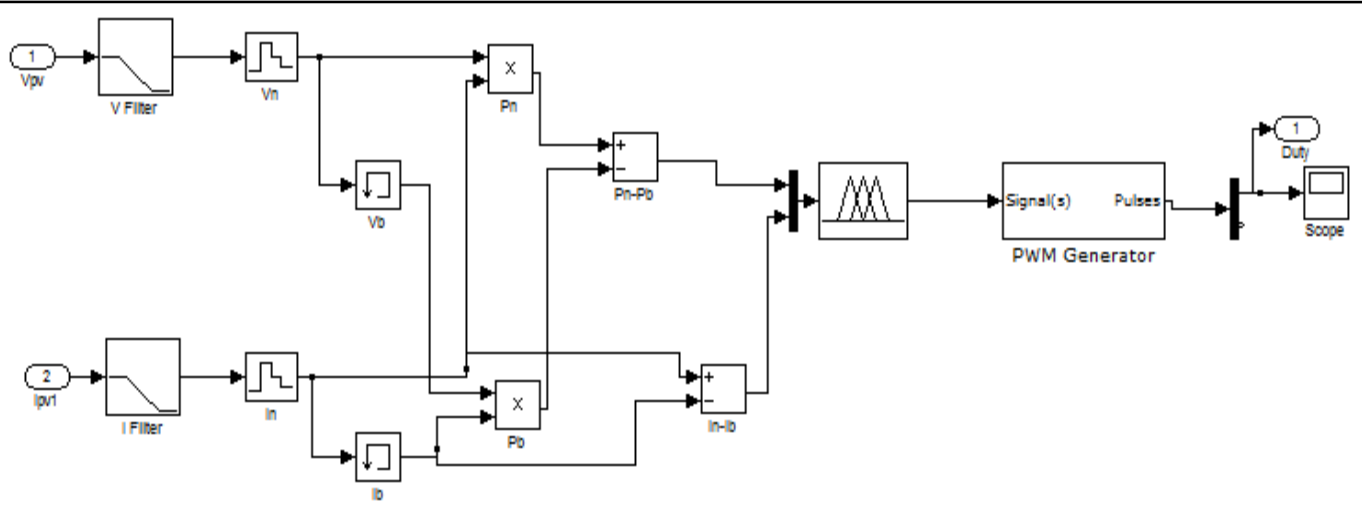

Figure 15. Simulink Block IC-fuzzy Algorithm Using Variables $\Delta P$ and $\Delta I$

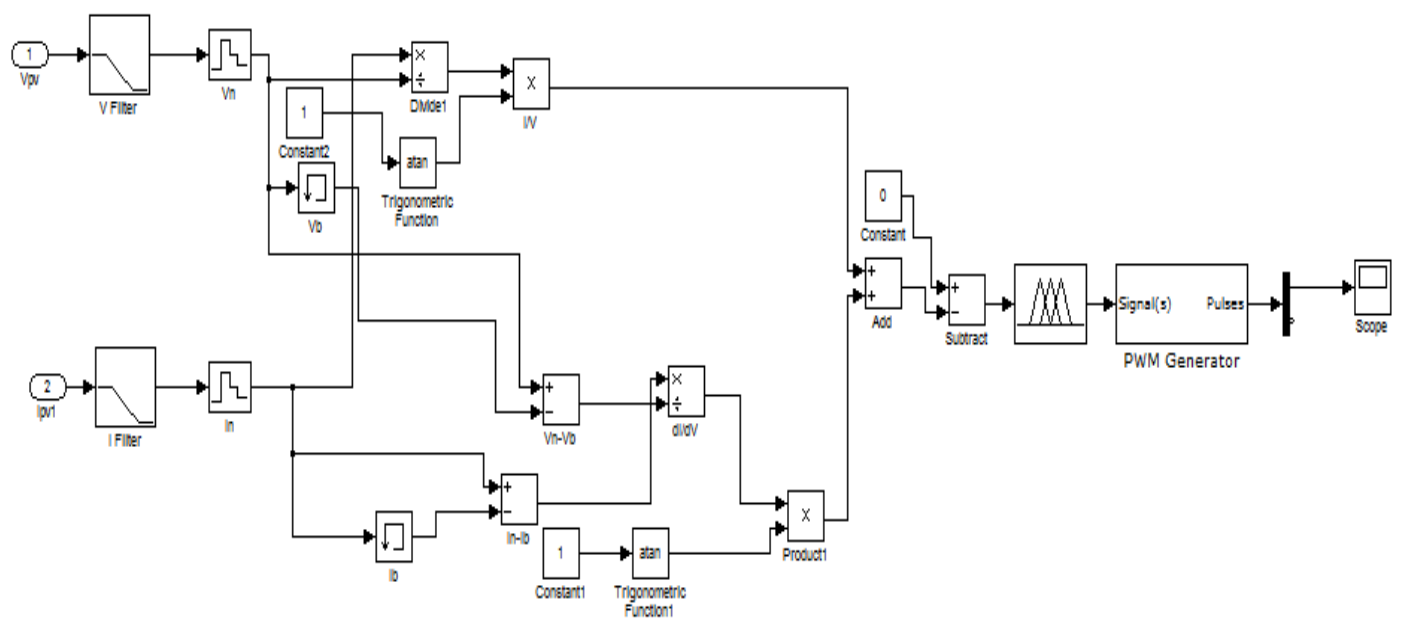

Figure 16. Simulink Block IC-Fuzzy Algorithm Using Tangent Variable
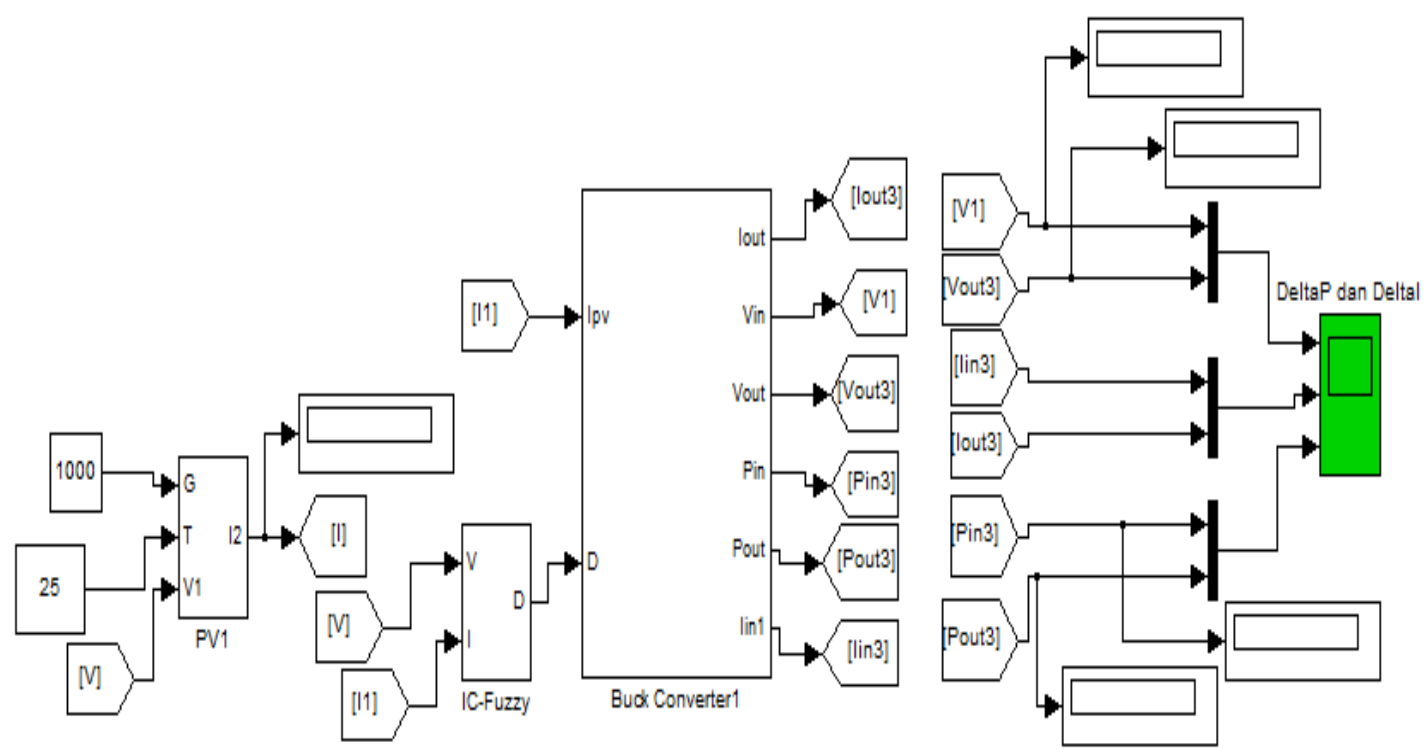

Figure 17. Simulink Block of Overall Fuzzy Modeling

\section{Research Results and Discussion}

This chapter will discuss the testing based on the planning of the system created. The system test is completed by simulation using MATLAB Simulink. This test is conducted to determine the reliability of the system and to determine whether the system in accordance with the desired planning. Tests conducted in this chapter are as follows: 
1. Testing solar cell characteristic

2. Testing Maximum Power Point Tracking (MPPT)

3. Testing the influences of irradiation and temperature alteration to algorithm on MPPT

\subsection{Result of Power Increment PV 1200 Watt}

Based on the solar cell simulation results, it is generated 1200 Watts of power, output voltage of 32.9 volts and current output of 49.12 amperes. Figure 18 shows curve characteristic curves of the solar cell output.

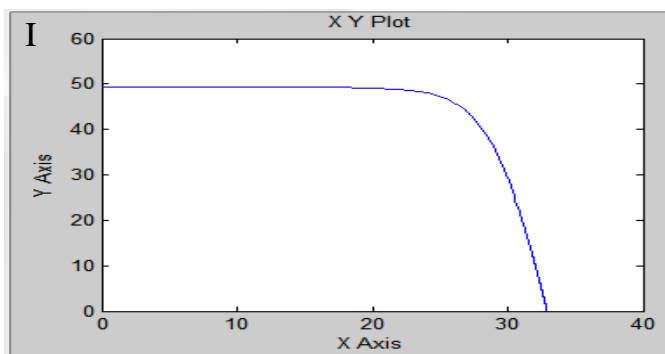

(a)

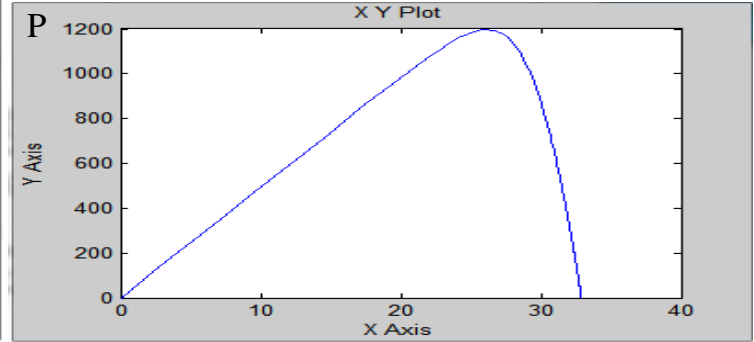

(b)

Figure 18. Curve Characteristic of Solar Cell: (a) Curve Relationship between I-V; and (b) Curve Relationship between $P$-V

\subsection{Simulation Results of MPPT Testing}

At this stage, the test to be conducted is testing the performance of solar cells without MPPT, then using conventional algorithm and followed by testing combined algorithm of P\&Ofuzzy and IC-fuzzy. Table 7 shows the overall results of solar cell simulations without using MPPT, using conventional algorithm and using combined algorithm. Meanwhile, Figures 19 to 20 show the signal results in simulations without using MPPT, using conventional algorithms and using combined algorithms.

Table 7. Overall Solar Cell Simulation Result

\begin{tabular}{ccccccccc}
\hline Algorithm & $\begin{array}{c}\text { lin } \\
(\mathrm{A})\end{array}$ & $\begin{array}{c}\text { lout } \\
(\mathrm{A})\end{array}$ & $\begin{array}{c}\text { Vin } \\
(\mathrm{V})\end{array}$ & $\begin{array}{c}\text { Vout } \\
(\mathrm{V})\end{array}$ & $\begin{array}{c}\text { Pin } \\
(\mathrm{W})\end{array}$ & $\begin{array}{c}\text { Pout } \\
(\mathrm{V})\end{array}$ & $\begin{array}{c}\text { Power } \\
\text { Efficiency } \\
(\%)\end{array}$ & $\begin{array}{c}\text { MPP } \\
\begin{array}{c}\text { Performance } \\
\text { Duration }\end{array}\end{array}$ \\
\hline Without & 31.23 & 50.04 & 29.72 & 14.27 & 928.1 & 714.1 & 76,93 & - \\
MPPT & 17.59 & 60.94 & $24.9 \mathrm{~V}$ & 15.54 & 1185 & 947.2 & 79 & 0.1 \\
P\&O & 47.59 & 60.15 & 24.63 & 15.61 & 1178 & 938.9 & 79 & 0.0125 \\
IC & 47.59 & \\
\hline & 40.83 & 56.61 & 27.97 & 15.94 & 1142 & 902.4 & 79 & \\
P\&O-fuzzy & 28.63 & 49.71 & 30.07 & 14.13 & 860.8 & 702.5 & 81 & \\
& 28.63 & 49.71 & 30.07 & 14.13 & 860.8 & 702.5 & 81 & \\
IC-fuzzy & 30.59 & 52.14 & 29.8 & 14.6 & 911.8 & 761 & 83 & 0.0055 \\
& 46.08 & 61.5 & 26.06 & 16.72 & 1201 & 1028 & 85.6 & 0.008 \\
\hline
\end{tabular}

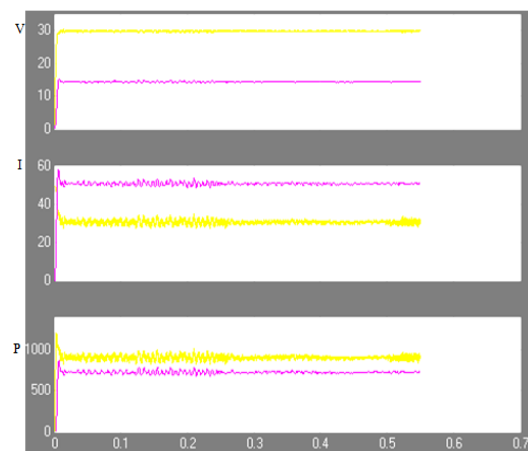

(a)

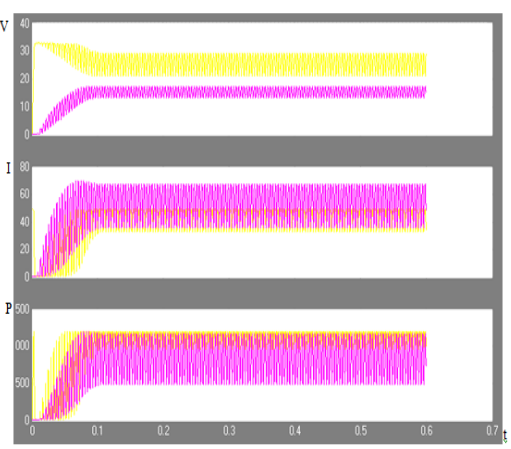

(b)

Figure 19. Results of Voltage, Current and Power Signals: (a) Signals without Using MPPT; and (b) Signals Using Conventional P\&O Algorithm 


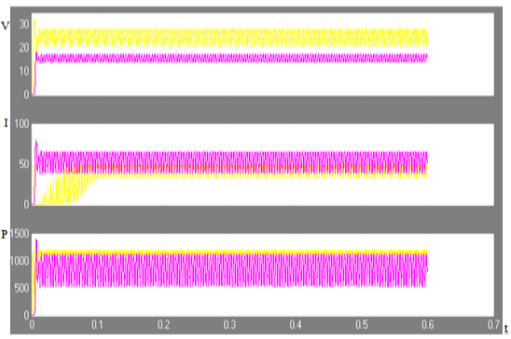

(a)

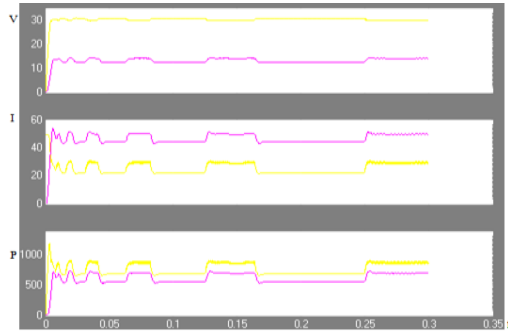

(c)

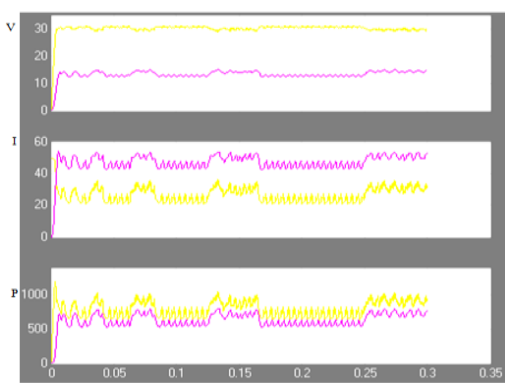

(e)

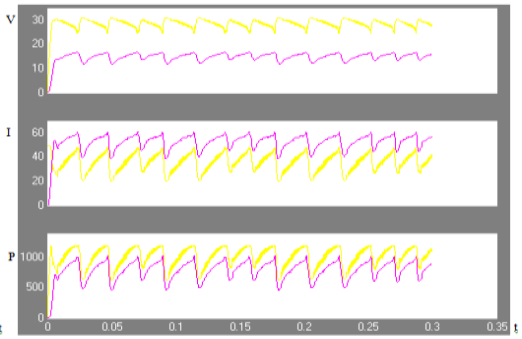

(b)

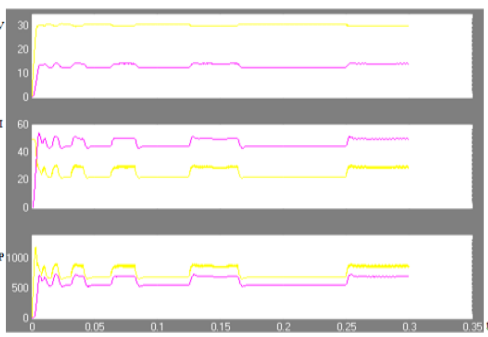

(d)

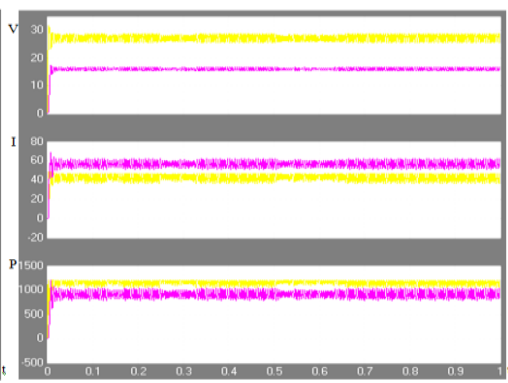

(f)

Figure 20. Results of Voltage, Current and Power Signals: (a) Signals Using Conventional IC Algorithm; (b) Signals Using P\&O-Fuzzy Combined Algorithm for Variables $\Delta P \& \Delta V$; (c) Signals Using P\&O-Fuzzy Combined Algorithm for Variables S \& $\Delta S$; (d) Signals Using P\&O-Fuzzy Combined Algorithms for Variable $S \& \Delta P$; (e) Signals Using IC-Fuzzy Combined Algorithm for Variables $\triangle P$ \& $\Delta l$; and (f) Signals Using IC-Fuzzy Combined Algorithm for Tangent Variables.

After testing solar cells without MPPT or with P\&O, IC, P\&O-fuzzy and IC-fuzzy algorithms using light intensity with a fixed temperature, the results achieved that the output of power and power efficiency produced by the combined algorithm is better without MPPT or using conventional algorithm. Moreover the power tracking generated by combined algorithm is faster, recorded by $0.0055 \mathrm{~s}-0.008 \mathrm{~s}$. Meanwhile, conventional algorithm produces tracking power of $0.1 \mathrm{~s}$ and $0.0125 \mathrm{~s}$. The oscillation result of the combined algorithm is quite low compared to that of conventional algorithm, primarily on the IC-fuzzy algorithm with tangent variables. The output power is quite decent, equal to 1028 Watts. The temperature used in this test is ideal temperature of $25^{\circ} \mathrm{C}$ with light intensity of $1000 \mathrm{~W} / \mathrm{m}^{2}$.

\subsection{Testing using Irradiation and Temperature Alteration}

Testing with alteration on solar irradiation and the given temperature is conducted by altered irradiation of $1000 \mathrm{~W} / \mathrm{m}^{2}, 900 \mathrm{~W} / \mathrm{m}^{2}$ and $800 \mathrm{~W} / \mathrm{m}^{2}$; meanwhile, the temperature is given by 25,30 and 35 . Tables 8 to 13 show the results of measuring fluctuating irradiation and temperature.

In tables 8 to 13 , it can be seen that the result of solar cell testing on alterations in the solar intensity using $\mathrm{P} \& \mathrm{O}$ and IC algorithms is decrease in the solar intensity leading to decrease in the generated power. It is due to the decrement on the current and voltage generated on solar cells. In utilizing P\&O-fuzzy and IC-fuzzy algorithms, the voltages and currents also decrease, but the voltage drop is insignificant,

KINETIK Vol. 3, No. 2, May 2018: 119-134 
While the results of testing solar cells in responding to temperature alteration show the greater the temperature is given, the generated power will be lower. That is because the solar cell temperature affects the generated current and output voltage on the solar cells, so the voltage becomes unstable and the current also decreases. Higher temperatures will affect solar cell performance, especially on the power generated. It is the working nature of the solar cell itself that the solar cell is receiving the amount of incoming sunlight not the amount of temperature. It happens to all algorithms tested in this study.

Table 8. Overall Results of Irradiation Alteration Using P\&O and IC Algorithm

\begin{tabular}{cccccccc}
\hline $\begin{array}{c}\text { Irradiation } \\
\mathrm{W} / \mathrm{m}^{2}\end{array}$ & $\begin{array}{c}\text { Temperature } \\
\left({ }^{\circ} \mathrm{C}\right)\end{array}$ & $\begin{array}{c}\text { lout } \\
\mathrm{P} \& \mathrm{O} \\
(\mathrm{A})\end{array}$ & $\begin{array}{c}\text { lout IC } \\
(\mathrm{A})\end{array}$ & $\begin{array}{c}\text { Vout P\&O } \\
(\mathrm{V})\end{array}$ & $\begin{array}{c}\text { Vout IC } \\
(\mathrm{V})\end{array}$ & $\begin{array}{c}\text { Pout P\&O } \\
(\mathrm{W})\end{array}$ & $\begin{array}{c}\text { Pout P\&O } \\
(\mathrm{W})\end{array}$ \\
\hline 1000 & & 60.94 & 59.92 & 15.54 & 14.89 & 947.2 & 938.9 \\
900 & 25 & 59.91 & 60.15 & 14.88 & 15.61 & 891.7 & 938.9 \\
800 & & 58.92 & 56.83 & 14.26 & 14.72 & 840.5 & 703 \\
\hline Average & & 59.92 & 56.39 & 14.89 & 14.6 & 893.13 & 826.12 \\
\hline
\end{tabular}

Table 9. Overall Results of Temperature Alteration Using P\&O and IC Algorithm

\begin{tabular}{cccccccc}
\hline $\begin{array}{c}\text { Irradiation } \\
\mathrm{W} / \mathrm{m}^{2}\end{array}$ & $\begin{array}{c}\text { Temperature } \\
\left({ }^{\circ} \mathrm{C}\right)\end{array}$ & $\begin{array}{c}\text { lout } \\
\mathrm{P} \& \mathrm{O} \\
(\mathrm{A})\end{array}$ & $\begin{array}{c}\text { lout IC } \\
(\mathrm{A})\end{array}$ & $\begin{array}{c}\text { Vout P\&O } \\
(\mathrm{V})\end{array}$ & $\begin{array}{c}\text { Vout IC } \\
(\mathrm{V})\end{array}$ & $\begin{array}{c}\text { Pout P\&O } \\
(\mathrm{W})\end{array}$ & $\begin{array}{c}\text { Pout P\&O } \\
(\mathrm{W})\end{array}$ \\
\hline \multirow{3}{*}{1000} & 25 & 60.94 & 60.15 & 15.54 & 15.61 & 947.2 & 938.9 \\
& 30 & 58.71 & 58.57 & 15.2 & 15.22 & 892.3 & 891.3 \\
& 35 & 56.85 & 56.85 & 14.79 & 14.79 & 840.6 & 840.6 \\
\hline Average & & 58.83 & 58.23 & 15.17 & 15.20 & 893.66 & 890.26 \\
\hline
\end{tabular}

Table 10. Overall Results of Irradiation Alteration Using P\&O-Fuzzy Algorithm

\begin{tabular}{|c|c|c|c|c|c|c|c|}
\hline $\begin{array}{c}\text { irradiation } \\
\mathrm{W} / \mathrm{m}^{2}\end{array}$ & $\begin{array}{c}\text { Temperature } \\
\left({ }^{\circ} \mathrm{C}\right)\end{array}$ & $\begin{array}{c}\text { lout } \\
\Delta \mathrm{P} \& \\
\Delta \mathrm{V}(\mathrm{A})\end{array}$ & $\begin{array}{c}\text { lout } \\
S \& \& S ; \\
S \& \Delta P \\
\text { (A) }\end{array}$ & $\begin{array}{c}\text { Vout } \\
\Delta \mathrm{P} \& \Delta \mathrm{V} \\
\text { (V) }\end{array}$ & $\begin{array}{c}\text { Vout } \\
\text { S \& } \& \text {; } \\
\text { S \& } \Delta \mathrm{P} \\
\text { (V) }\end{array}$ & $\begin{array}{c}\text { Pout } \\
\Delta \mathrm{P} \& \Delta \mathrm{V} \\
\text { (W) }\end{array}$ & $\begin{array}{c}\text { Pout } \\
S \text { \& } \Delta \text {; } \\
S \& \Delta P \\
\text { (W) }\end{array}$ \\
\hline 1000 & & 56.61 & 49.71 & 15.94 & 14.13 & 902.4 & 702.5 \\
\hline 900 & 25 & 53.7 & 49 & 15.25 & 13.93 & 816.1 & 682.6 \\
\hline 800 & & 52.5 & 48.08 & 14.82 & 13.67 & 783.3 & 657.1 \\
\hline Average & & 54.27 & 48.93 & 15.33 & 13.91 & 893.93 & 689.73 \\
\hline
\end{tabular}

Table 11. Overall Results of Irradiation Alteration Using IC-Fuzzy Algorithm

\begin{tabular}{|c|c|c|c|c|c|c|c|}
\hline $\begin{array}{l}\text { Irradiation } \\
\mathrm{W} / \mathrm{m}^{2}\end{array}$ & $\begin{array}{c}\text { Temperature } \\
\left({ }^{\circ} \mathrm{C}\right)\end{array}$ & $\begin{array}{c}\text { lout } \\
\Delta \mathrm{P} \& \\
\Delta \mathrm{I} \\
(\mathrm{A})\end{array}$ & $\begin{array}{l}\text { lout } \\
\text { tangent } \\
\text { (A) }\end{array}$ & $\begin{array}{l}\text { Vout } \\
\Delta \mathrm{P} \& \Delta \mathrm{l} \\
\text { (V) }\end{array}$ & $\begin{array}{l}\text { Vout } \\
\text { tangent } \\
\text { (V) }\end{array}$ & $\begin{array}{c}\text { Pout } \\
\Delta \mathrm{P} \& \Delta \mathrm{l} \\
\text { (W) }\end{array}$ & $\begin{array}{l}\text { Pout } \\
\text { tangent } \\
\text { (W) }\end{array}$ \\
\hline 1000 & & 52.14 & 61.47 & 14.6 & $16.7 a^{\prime}$ & 76 & 1028 \\
\hline $\begin{array}{l}900 \\
800\end{array}$ & 25 & $\begin{array}{l}51.29 \\
50.49\end{array}$ & $\begin{array}{l}58.83 \\
54.25\end{array}$ & $\begin{array}{l}14.32 \\
14.17\end{array}$ & $\begin{array}{l}15.77 \\
14.71\end{array}$ & $\begin{array}{l}734.5 \\
715.4\end{array}$ & $\begin{array}{l}927.7 \\
798.1\end{array}$ \\
\hline erage & & 1.30 & 58.18 & 14.36 & 15.73 & 736.96 & 917.93 \\
\hline
\end{tabular}

Table 12. Overall Results of Temperature Alteration Using P\&O-Fuzzy Algorithm

\begin{tabular}{|c|c|c|c|c|c|c|c|}
\hline $\begin{array}{l}\text { Irradiation } \\
\mathrm{W} / \mathrm{m}^{2}\end{array}$ & $\begin{array}{c}\text { Temperature } \\
\left({ }^{\circ} \mathrm{C}\right)\end{array}$ & $\begin{array}{c}\text { lout } \\
\Delta \mathrm{P} \& \\
\Delta \mathrm{V} \\
(\mathrm{A})\end{array}$ & $\begin{array}{c}\text { lout } \\
\text { S \& } 8 \text {; } \\
S \& \Delta P \\
\text { (A) }\end{array}$ & $\begin{array}{c}\text { Vout } \\
\Delta \mathrm{P} \& \Delta \mathrm{V} \\
(\mathrm{V})\end{array}$ & $\begin{array}{c}\text { Vout } \\
S \& \Delta S ; \\
S \& \Delta P \\
\quad(V)\end{array}$ & $\begin{array}{c}\text { Pout } \\
\Delta \mathrm{P} \& \Delta \mathrm{V} \\
\text { (W) }\end{array}$ & $\begin{array}{c}\text { Pout } \\
S \& \Delta S ; \\
S \& \Delta P \\
\text { (W) }\end{array}$ \\
\hline & 25 & 56.61 & 49.71 & 15.94 & 14.13 & 902.4 & 702.5 \\
\hline \multirow{2}{*}{1000} & 30 & 55.93 & 47.93 & 15.76 & 13.62 & 881.1 & 653.1 \\
\hline & 35 & 52.91 & 46.15 & 14.81 & 13.12 & 783.5 & 605.4 \\
\hline Average & & 5.15 & 47.93 & 15.50 & 13.62 & 855.66 & 653.66 \\
\hline
\end{tabular}




\begin{tabular}{|c|c|c|c|c|c|c|c|}
\hline $\begin{array}{l}\text { Irradiation } \\
\mathrm{W} / \mathrm{m}^{2}\end{array}$ & $\begin{array}{c}\text { Temperature } \\
\left({ }^{\circ} \mathrm{C}\right)\end{array}$ & $\begin{array}{c}\text { lout } \\
\Delta \mathrm{P} \& \\
\Delta \mathrm{l} \\
(\mathrm{A})\end{array}$ & $\begin{array}{c}\text { lout } \\
\text { tange } \\
n t \\
\text { (A) }\end{array}$ & $\begin{array}{l}\text { Vout } \\
\Delta \mathrm{P} \& \Delta \mathrm{I} \\
(\mathrm{V})\end{array}$ & $\begin{array}{l}\text { Vout } \\
\text { tangent } \\
\text { (V) }\end{array}$ & $\begin{array}{l}\text { Pout } \\
\Delta \mathrm{P} \& \Delta \mathrm{I} \\
\text { (W) }\end{array}$ & $\begin{array}{l}\text { Pout } \\
\text { tangent } \\
\text { (W) }\end{array}$ \\
\hline \multirow{3}{*}{1000} & 25 & 52.14 & 61.47 & 14.6 & 16.72 & 761 & 1028 \\
\hline & 30 & 50.23 & 57.9 & 14.04 & 15.89 & 705.4 & 920.1 \\
\hline & 35 & 47.33 & 55.64 & 13.81 & 15.41 & 653.4 & 857.6 \\
\hline verage & & & 58.33 & 14.15 & 16.00 & 706.6 & 935.23 \\
\hline
\end{tabular}

\section{Conclusion}

The design of P\&O-fuzzy and IC-fuzzy algorithms achieve better performance compared with ordinary algorithm, with oscillation resulted by P\&O-fuzzy and IC-fuzzy combined algorithms is quite low compared to conventional P\&O and IC algorithm. The MPPT performance in power search time on P\&O-fuzzy and IC-fuzzy combined algorithms is also faster than the ordinary algorithm by $0.0055 \mathrm{~s}-0.008 \mathrm{~s}$. Meanwhile, $\mathrm{P} \& \mathrm{O}$ and IC algorithm takes about $0.1 \mathrm{~s}-0.0125 \mathrm{~s}$. P\&Ofuzzy and IC-fuzzy algorithms using tangent variables can produce a maximum stability of 1028 Watts, with a low oscillation value.

In comparing P\&O-fuzzy with IC-fuzzy algorithms, IC-fuzzy algorithm shows better performance than the $\mathrm{P} \& \mathrm{O}$-fuzzy algorithm. By using tangent variable, the resulted performance is more maximal compared with other variables.

Solar cell performance without using MPPT results in power efficiency of $75 \%$ while using MPPT with conventional algorithm of power efficiency yields $79 \%$. P\&O-fuzzy and IC-fuzzy combined algorithm achieves power efficiency of $79 \%-85 \%$.

\section{Notations}

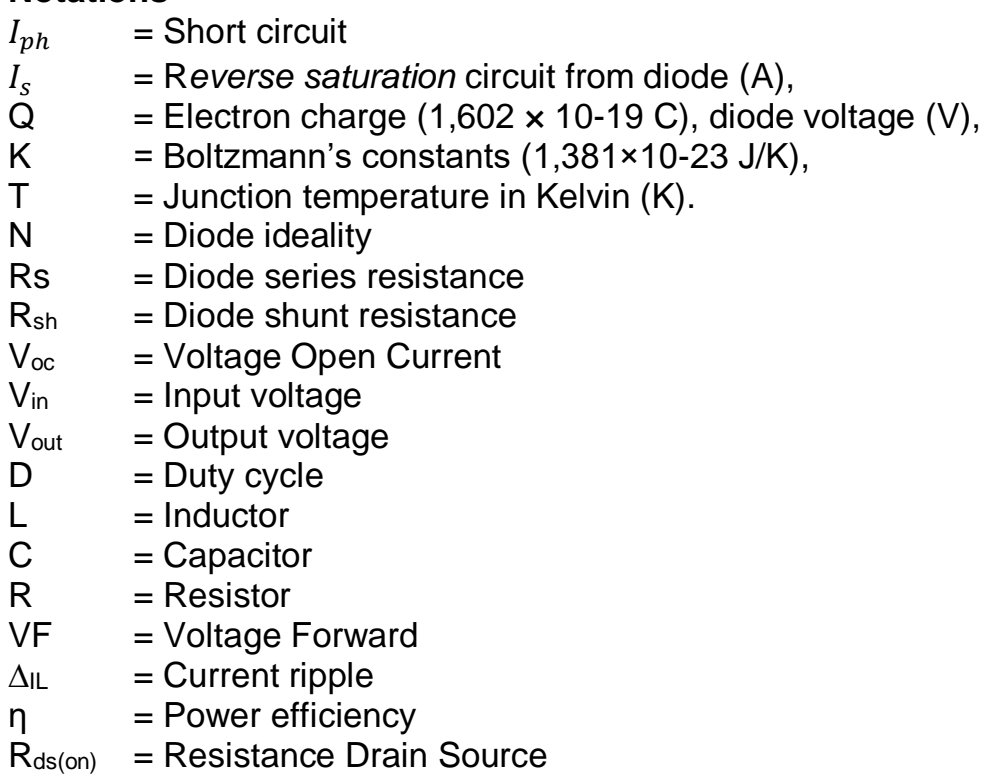

\section{References}

[1] Hegedus, S., and Luque, A., "Hand book of Photovoltaic Science and Engineering," 2003.

[2] Ahsanul, Ivan. K., "Maximum Optimization of Power Point Tracking (MPPT) on Solar-Wind Turbine Using Incremental Conductance Method," 2017.

[3] Tito, Bang, "MPPT Method for Solar Cell Based on PI Controller," 2012.

[4] Nema, S., Nema, R.K., and Agnihotri, G., "MATLAB Simulink Based Study of Photovoltaic Cell Module Array and Their Experimental Verification," International Journal of Energy and Environmental, 2010.

[5] Esram, T., Chapman, and P. L., "Comparison of Photovoltaic Array Maximum Power Point Tracking," 2007. 
[6] Harmini, "Implementation of Maximum Power Point Tracking (MPPT) DC-DC Converter on Photovoltaic System Using P\&O Algorithm and Incremental," 2010.

[7] Shiau, Jaw-Kuen, "A Study on the Fuzzy-Logic-Based Solar Power MPPT Algorithms Using Different Fuzzy Input Variables," 2015.

[8] Ananduta, Wayan, W., "Simulation Analysis of Maximum Power Point Tracker System Based on Boost Converter Circuit," 2011.

[9] Kalmin, Akhmad, "Solar Module Simulation and Verification Connected to Boost Converter on Direct Current Micro Electric Circuit Using Matlab Simulink," 2012.

[10] Effendy, Machmud, "Maximum Power Point Design and Tracking (MPPT) on Solar Cell System Applications in Wind Power Grid (PLTA)," 2013. 
